\title{
Determining the Effect of Drying Time on Phosphorus Solubilization from Three Agricultural Soils under Climate Change Scenarios
}

\author{
K. J. Forber, ${ }^{*}$ M. C. Ockenden, C. Wearing, M. J. Hollaway, P. D. Falloon, R. Kahana, M. L. Villamizar, J. G. Zhou, \\ P. J. A. Withers, K. J. Beven, A. L. Collins, R. Evans, K. M. Hiscock, C. J. A. Macleod, and P. M. Haygarth
}

\begin{abstract}
Climate projections for the future indicate that the United Kingdom will experience hotter, drier summers and warmer, wetter winters, bringing longer dry periods followed by rewetting. This will result in changes in phosphorus $(P)$ mobilization patterns that will influence the transfer of $P$ from land to water. We tested the hypothesis that changes in the future patterns of drying-rewetting will affect the amount of soluble reactive phosphorus (SRP) solubilized from soil. Estimations of dry period characteristics (duration and temperature) under current and predicted climate were determined using data from the UK Climate Projections (UKCP09) Weather Generator tool. Three soils (sieved $<2 \mathrm{~mm}$ ), collected from two regions of the United Kingdom with different soils and farm systems, were dried at $25^{\circ} \mathrm{C}$ for periods of $0,2,4,5,6,8,10,15,20,25,30,60$, and $90 \mathrm{~d}$, then subsequently rewetted ( $50 \mathrm{~mL}$ over $2 \mathrm{~h}$ ). The solubilized leachate was collected and analyzed for SRP. In the 2050s, warm period temperature extremes $>25^{\circ} \mathrm{C}$ are predicted in some places and dry periods of 30 to $90 \mathrm{~d}$ extremes are predicted. Combining the frequency of projected dry periods with the SRP concentration in leachate suggests that this may result overall in increased mobilization of P; however, critical breakpoints of 6.9 to $14.5 \mathrm{~d}$ dry occur wherein up to $28 \%$ more SRP can be solubilized following a rapid rewetting event. The precise cause of this increase could not be identified and warrants further investigation as the process is not currently included in P transfer models.
\end{abstract}

\section{Core Ideas}

- UK Climate Projections predict long dry hot periods followed by intense rainfall.

- Frequency of longer dry periods increase under climate change.

- Critical breakpoints of 7-15 dry days have been identified that solubilize more $\mathrm{P}$ from soil.

- Increased dry period frequency will result in an overall increase in SRP concentration solubilized.

\footnotetext{
Copyright $\odot$ American Society of Agronomy, Crop Science Society of America, and Soil Science Society of America. 5585 Guilford Rd., Madison, WI 53711 USA. All rights reserved.

J. Environ. Qual. 46:1131-1136 (2017)

doi:10.2134/jeq2017.04.0144

This is an open access article distributed under the terms of the CC BY license

(https://creativecommons.org/licenses/by/4.0/)

Supplemental material is available online for this article.

Received 11 Apr. 2017.

Accepted 22 Aug. 2017

*Corresponding author (k.forber@lancaster.ac.uk).
}

A

GRICULTURAL diffuse pollution from soil causes significant pressure on water quality (European Commission, 2012). The challenges of mitigating agricultural phosphorus $(\mathrm{P})$ pollution are complex (Kleinman et al., 2015), and despite significant efforts to reduce diffuse P pollution, evidence suggests success is rare and poor water quality proliferates (Jarvie et al., 2013). Such challenges will become more prevalent as pressures driven by climate change increase.

In large parts of Europe, the frequency of warm days (i.e., heat waves) has likely increased (IPCC, 2014). Globally, the probability of heat waves occurring has more than doubled in some locations (IPCC, 2014). The UK Climate Projections (UKCP09; UKCP, 2009) provides probabilistic estimates for temperature change and other climatic variables (which do not include event duration, e.g., dry spells) in the United Kingdom. Under a medium emissions scenario, the mean annual temperature in England is projected to increase between 0.9 and $4.0^{\circ} \mathrm{C}$ by the 2050 s when compared to the 1961 to 1990 climate mean, with a central estimate of $3.6^{\circ} \mathrm{C}$ warming. Summer temperatures are projected to rise even more, $\left(1.0-4.6^{\circ} \mathrm{C}\right)$ with a central estimate of $4.1^{\circ} \mathrm{C}$ and higher increases in the southeast of England $\left(1.3-4.6^{\circ} \mathrm{C}\right)$ than the northwest of England $\left(1.2-4.1^{\circ} \mathrm{C}\right)$. Summer rainfall is also likely to decrease in both the northwest ( -36 to $1 \%$ ) and the southeast ( -41 to $7 \%$ ) of England. Current high resolution climate models $(1.5-\mathrm{km}$ grid spacing) indicate that hourly rainfall intensities will increase in both summer and winter months (Kendon et al., 2014). Hence, dry periods of increased duration followed by intense rewetting will likely become more prevalent. For catchments where the main source of $\mathrm{P}$ is agricultural, most annual total $\mathrm{P}$ loads are transferred during high discharge events (Ockenden et al., 2016), of which a

\footnotetext{
K.J. Forber, M.C. Ockenden, C. Wearing, M.J. Hollaway, K.J. Beven, and P.M. Haygarth, Lancaster Environment Centre, Lancaster Univ., Lancaster LA1 4YQ, England; P. D. Falloon and R. Kahana, Met Office Hadley Centre, Exeter, Devon EX1 3PB, England; M.L. Villamizar, School of Engineering, Liverpool Univ., L69 3GQ, England; J.G. Zhou, School of Computing, Mathematics and Digital Technology, Manchester Metropolitan Univ., Manchester M1 5GB, England; P.J.A. Withers, Bangor Univ., Bangor, Gwynedd LL58 8RF, Wales; A.L. Collins, Rothamsted Research North Wyke, Okehampton, Devon EX20 2SB, England; R. Evans, Global Sustainability Institute, Anglia Ruskin Univ., Cambridge CB1 1PT, England; K.M. Hiscock, Univ. of East Anglia, Norwich NR4 7TJ, England; C.J.A. Macleod, James Hutton Institute, Aberdeen AB15 8QH, Scotland. Assigned to Associate Editor Sam Carrick.
}

Abbreviations: DRW, drying-rewetting; DTC, demonstration test catchment; SRP, soluble reactive phosphorus; UKCP09, UK Climate Projections. 
significant portion is bioavailable dissolved P (Joosse and Baker, 2011). Therefore, increased frequency of extreme meteorological and hydrological events in the future is likely to increase the transfer of P to water bodies (Ockenden et al., 2016), increasing the risk of eutrophication. It seems likely that climate change will alter the degree, rate, and frequency of drying-rewetting (DRW) events, so altering the nutrient cycling of $\mathrm{P}$ within soils as it undergoes both abiotic and biotic stress. Such changes may alter the amount and form of $\mathrm{P}$ mobilized via solubilization and detachment, consequently increasing the amount of $\mathrm{P}$ that can undergo transport and affect watercourses, as described by the P transfer continuum (Haygarth et al., 2005).This is especially important to consider into the future as, although net $\mathrm{P}$ inputs to land may decline, accumulated $\mathrm{P}$ stores will continue to be mobilized, posing continual and long-term risks to watercourses (Powers et al., 2016).

Evidence suggests that DRW events cause an increase in soil nutrient availability in leachate (Blackwell et al., 2009, 2012; Bünemann et al., 2013; Butterly et al., 2011b; Nguyen and Marschner, 2005; Soinne et al., 2010; Xu et al., 2011). Drying soils to a gravimetric water content of $<10 \%$ (w/w) significantly increases P mobilization at rewetting, especially at $<2.5 \%$ (Bünemann et al. (2013) and 2 to 4\% (Dinh et al., 2017). This increase in $\mathrm{P}$ availability in dried soil on rewetting has been attributed to microbial cell lysis (Turner and Haygarth, 2001), yet it is probable that a significant proportion is of nonmicrobial origin organic P or inorganic P (Blackwell et al., 2009; Bünemann et al., 2013; Butterly et al., 2009, 2011b). For example, high organic carbon (C) soils can result in significantly more available P after drying and rewetting (Nguyen and Marschner, 2005; Styles and Coxon, 2006). Chen et al. (2016) also found that frequent DRW cycles can cause greater, more long lasting impacts on soil biomass $\mathrm{P}$ dynamics than carbon dynamics. In addition, soils with high microbial biomasses yield more P on rewetting (Styles and Coxon, 2006), especially if the community is not resilient to DRW cycles (Butterly et al., 2011a; Fierer et al., 2002; Pailler et al., 2014; Wang et al., 2013). Drying can induce the oxidation of soil organic $\mathrm{C}-\mathrm{Fe}$ and $-\mathrm{Al}$ associations (Bartlett and James, 1980; Haynes and Swift, 1985; Schlichting and Leinweber, 2002) and thus directly release organic P and indirectly release inorganic $\mathrm{P}$ via mineralization that is subsequently stimulated (Styles and Coxon, 2006). Slaking has also been identified as one the most important mechanisms to disrupt soil aggregate structure and integrity, exposing specific surface areas to desorb both inorganic and organic P (from nonliving organic matter) from dried soil as it is rewetted (Bünemann et al., 2013; Chepkwony et al., 2001). Upon drying without rewetting however, some (peat) soils can further adsorb more $\mathrm{P}$ associated with these organic matter complexes (which are also more extractable if rewetted) (Schlichting and Leinweber, 2002). This has been observed in the field in western Ireland, where during summer, lower moisture contents and higher $P$ sorption capacities can buffer against P loss even following P application (Styles and Coxon, 2007).

Despite this, as far as we are aware, there is no literature on the effect of the duration of drying period of the soil on the solubilization of $\mathrm{P}$ after a rapid rewetting event. This needs to be known if we are to consider the effects of predicted climatic change. In addition, such information may help inform land managers of optimum P application timings during the growing season.
Our experiment was designed to inform a multimodel exercise that explores model performance and/or prediction of transport of nutrients in the Defra (Department for the Environment and Rural Affairs)-funded UK Demonstration Test Catchments (DTCs) (McGonigle et al., 2014) under climate change. In this study, three subcatchments were chosen to represent two of the DTCs. These subcatchments are included in extensive catchment-scale research platforms that explore the effects of diffuse agricultural pollution on stream ecosystems (Ockenden et al., 2016; Outram et al., 2014, 2016; Snell et al., 2014; Wade et al., 2012). In this study, we test the hypothesis that changes in the future patterns of DRW will affect the amount of soluble reactive phosphorus (SRP) solubilized. The specific objectives were (i) to determine how the duration and frequency of dry periods would change from present day to the future (2050) at the local scale for three UK catchments; (ii) to use laboratory experiments on soils from the three catchments to determine how the duration of drying period before an intense rewetting event affects the amount of SRP solubilized and measured in leachate; and (iii) to combine the frequency and duration of future dry periods with the results of laboratory experiments to estimate how total SRP solubilized after DRW events may change.

\section{Materials and Methods}

\section{Estimation of Dry Period Characteristics}

The UKCP09 Weather Generator (UKCP, 2009) was used to determine characteristics of temperature $\left(25^{\circ} \mathrm{C}\right.$ for extreme dry periods) and dry period duration in the future (up to $90 \mathrm{~d}$ ), which were used to inform the DRW event in our experiment. Further details are given in Supplemental Material.

\section{Choice of Sampling Location}

Soils were chosen to represent the different land uses and soils within the Eden and Wensum DTCs. Newby Beck $\left(12.5 \mathrm{~km}^{2}\right.$, $\left.54.59^{\circ} \mathrm{N}, 2.62^{\circ} \mathrm{W}\right)$ and Pow Beck $\left(10.5 \mathrm{~km}^{2}, 54.84^{\circ} \mathrm{N}, 2.96^{\circ} \mathrm{W}\right)$ are two rural headwater subcatchments within the Eden DTC, Cumbria, UK. The Newby Beck subcatchment is predominantly improved grassland (76\%); soil was collected from a field that is grazed on rotation by sheep and dairy cattle $\left(\mathrm{P}_{2} \mathrm{O}_{5}\right.$ application rate $28.76 \mathrm{~kg} \mathrm{P} \mathrm{ha}^{-1}$ for 2014). Pow Beck is also predominantly improved grassland (46\%) and is more intensively farmed than Newby Beck; soil was collected from a field in which beef cattle are grazed (no recorded P applied for 2014). Limited fertilizer and slurry application data are available for these two catchments (see Supplemental Material). The Blackwater $\left(19.7 \mathrm{~km}^{2}\right.$, $52.78^{\circ} \mathrm{N}, 1.15^{\circ} \mathrm{E}$ ) is a subcatchment within the Wensum DTC, Norfolk, UK. Soil was also collected from an arable (winter wheat [Triticum aestivum L.]) field within the Blackwater (2013-2014 spring bean [Phaseolus vulgaris L.] rotation with an inorganic and organic P application rate of $1-49 \mathrm{~kg} \mathrm{P} \mathrm{ha}^{-1}$ [Outram et al., 2016]). Detailed farm business data for the Blackwater are published in Outram et al. (2016), and further information can be found in the Supplemental Material.

\section{Soil Type, Collection, and Preparation}

Soils from the Newby, Pow, and Blackwater catchments were collected from the top $25 \mathrm{~cm}$ of soil at one point in a single field between September and October 2014. Small sampling pits were 
dug and a bulk sample was removed inclusive of plant material present. Soil samples were sieved wet to $2 \mathrm{~mm}$, removing visible plant and root material, and kept in sealed bags at $4^{\circ} \mathrm{C}$ until use. Soils from the Newby and Pow catchments are similar (Typic Haplaquept Inceptisols or Chromic Eutric Albic Luvic Stagnosols [Cranfield University, 2017; IUSS Working Group WRB, 2015]), the Newby soil being of fine loamy texture, and the Pow soil fine and coarse loamy. The Blackwater soil (Aquic Dystrochept Inceptisol or Endostagnic Luvisols [Cranfield University, 2017; IUSS Working Group WRB, 2015]) is a loamy and clayey soil (NSRI, 2014), characterized by a subsurface accumulation of clays. For Olsen's P analysis, soil was air-dried to a constant weight and sieved to $2 \mathrm{~mm}$. For further chemical analysis, prepared soil was ground using a pestle and mortar for C, nitrogen $(\mathrm{N})$, and total soil $\mathrm{P}$ analysis. Soil $\mathrm{pH}$ was measured in a deionized water suspension using a Jenway 3510 according to Rowell (1994). Soil C and N percentages were measured using a Vario El Elemental Analyzer, and $\mathrm{C} / \mathrm{N}$ was calculated. Total soil $\mathrm{P}$ was determined by wet oxidation digestion (Rowland and Grimshaw, 1985) and Olsen's P was determined by the method of Olsen and Sommers (1982); both were measured according to Murphy and Riley (1962) (Seal Analytical AQ2+).

\section{Soil Drying and Rewetting}

Soils were prepared according to the method from Blackwell et al. (2009). Soils were pre-incubated at $25^{\circ} \mathrm{C}$ for $24 \mathrm{~h}$ prior to being dried. Soil samples of approximately $300 \mathrm{~g}$ were then air-dried undisturbed in a temperature-controlled room fixed at $25^{\circ} \mathrm{C}$ in $2-\mathrm{L}$ rectangular tubs for each drying increment. The temperature $\left(25^{\circ} \mathrm{C}\right)$ and maximum duration of dry period $(90 \mathrm{~d})$ were justified from UKCP09 as indicative of the most extreme dry periods in the future for these sites. Newby and Pow soils were dried for $0,2,4,5,6,8,10,15,20,25,30,60$, and $90 \mathrm{~d}$. The Blackwater soil was dried for $0,5,10,15,20,25,30,60$, and 90 $\mathrm{d}$ as a limited amount of soil was available. Matric potential was measured using a Decagon WP4-C Dewpoint Potentiometer in three subsamples for each drying period. Five subsamples $(21 \mathrm{~g}$ dry wt. equivalent) of soil for each drying period were removed and placed into $50-\mathrm{mL}$ plastic conical funnels each plugged with $0.3 \mathrm{~g}$ of nonabsorbent glass wool. The soil was loosely packed in the funnel by gently tapping and placed in a centrifuge tube. All soil was then rewetted over $2 \mathrm{~h}(50 \mathrm{~mL}$, pipetting 5 -mL aliquots evenly spaced over $2 \mathrm{~h}$ ); $0.45-\mu \mathrm{m}$ Whatman filter paper was placed on the soil surface to aid even distribution of water; leachate was collected in the centrifuge tube. A rewetting rate of $25 \mathrm{~mL}$ over $2 \mathrm{~h}$ was used in Blackwell et al. (2009) and resulted in the most significant leaching of dissolved $\mathrm{P}$ in those experiments; it was therefore doubled here to increase the intensity of the rewetting event. Filtered (using $0.45-\mu \mathrm{m}$ syringe filters) leachate samples were used to measure SRP according to Murphy and Riley (1962) using a Thermo Scientific Multiskan GO Plate Reader. Information regarding statistical analysis can be found in the Supplemental Material.

\section{Results and Discussion}

\section{Change in Duration and Temperature of Dry Period}

The 95th percentile (mean average over 100 runs) duration of dry periods increased in both catchments between the present day and the future scenario period; dry periods increased by up to $40 \%$ for the Blackwater and 25\% for Newby Beck (Supplemental Table S1). There was a 17,23 , and $7 \%$ increase in the frequency periods of 11- to 15-d dry in the Newby, Pow, and Blackwater catchments in the scenario period (Supplemental Fig. S1 and S2). The frequency of dry periods of $>16 \mathrm{~d}$ increased in the scenario period in all catchments; however, dry periods between 1 and $5 \mathrm{~d}$ either increased by $<1.5 \%$ (Newby and Pow) or decreased in frequency (Blackwater) under climate change (Supplemental Fig. S3). The 90th percentile of mean average temperature during dry periods (Supplemental Fig. S2) increased by $\sim 3^{\circ} \mathrm{C}$ in each catchment (Supplemental Table S2). Under climate change, longer periods of dry weather (extremes $90 \mathrm{~d}$ ) at higher temperatures (extremes $25^{\circ} \mathrm{C}$ ) may be experienced. These results were used to inform the laboratory experimental design to ensure the probabilistic range indicated by the weather generator was covered.

\section{Difference Between Soils in Different Catchments}

The $\mathrm{C}$ and $\mathrm{N}$ percentages for the Newby $(4.18,0.47)$ and Pow $(6.43,0.62)$ soils were greater than the Blackwater soil $(1.47,0.17)$ (Supplemental Table S2). The C/N ratios were calculated as $8.89,10.37$ and 8.65 for Newby, Pow, and Blackwater, respectively, with soil $\mathrm{pH}$ determined as 5.84, 5.56, and 5.78. The Blackwater soil had a lower initial total $\mathrm{P}$ content $(780 \mathrm{mg}$ $\mathrm{kg}^{-1}$ ) than Newby $\left(1600 \mathrm{mg} \mathrm{kg}^{-1}\right.$ ) and Pow (1200 mg kg-1) soils. Available P (Olsen's P) was the same in the Blackwater and Newby soils $\left(3.4 \mathrm{mg} \mathrm{kg}^{-1}\right)$; Pow had a highest content (12.8 $\mathrm{mg} \mathrm{kg}{ }^{-1}$ ). Moisture content for Newby, Pow, and Blackwater soils was $32.93,34.97$, and $14.65 \%$ respectively (Supplemental Table S2). The matric potential at $0 \mathrm{~d}$ dry was similar between soils, measured as $-0(0),-0.24(0.11)$, and $-0.46(0.095)$ for Newby, Pow, and Blackwater. Bulk density was not determined a priori in this experiment but was estimated for each soil type in this location as $1.22,1.2$, and $1.4 \mathrm{~g} \mathrm{~cm}^{-3}$ for Newby, Pow, and Blackwater, respectively (NSRI, 2014).

Figure 1 describes the concentration of SRP $\left(\mu \mathrm{g} \mathrm{L}^{-1}\right)$ in leachate subsequent to rewetting for each replicate at the individual drying increments. In the Pow and Newby soils, SRP concentrations were outside the detectable limit in leachate samples from soils dried between 0 and $2 \mathrm{~d}$; these are therefore reported as 0 . At $90 \mathrm{~d}$, the SRP concentration in leachate was higher than that reported at $0 \mathrm{~d}$ for all soils (Supplemental Table S4). However, the highest concentration of SRP was measured in leachate from soil dried for the duration of $15 \mathrm{~d}$ for Newby $(129.7 \pm 7.7 \mu \mathrm{g}$ $\left.\mathrm{L}^{-1}\right), 10 \mathrm{~d}$ for Pow $\left(68.1 \pm 23.2 \mu \mathrm{g} \mathrm{L}{ }^{-1}\right)$, and $20 \mathrm{~d}$ for Blackwater $\left(305.9 \pm 67.8 \mu \mathrm{g} \mathrm{L}^{-1}\right)$ soils. There was no significant difference between the volume of leachate collected at each drying increment; the mean average volume collected for Newby, Pow and Blackwater was $35.9( \pm 3.4), 38.7( \pm 3.4)$, and $40.3( \pm 2.1) \mathrm{mL}$, respectively. Therefore, the relationship between time dried and load of SRP ( $\mu \mathrm{g} P$ ) was similar to the relationship between time dried and concentration of SRP $\left(\mu \mathrm{g} \mathrm{L}^{-1}\right)$, as confidence intervals for the breakpoints overlap (Fig. 1, Supplemental Fig. S4).

Analysis identified breakpoints at $14.5 \pm 1.8 \mathrm{~d}\left(r^{2}=0.705\right)$ for Newby, $10.0 \pm 1.4 \mathrm{~d}\left(r^{2}=0.559\right)$ for Pow, and $6.9 \pm 2.3 \mathrm{~d}\left(r^{2}\right.$ $=0.311$ ) for Blackwater soils (Fig. 1, Table 1). Segmented linear regression identified a breakpoint in the data (performed in $\mathrm{R}$ using the Segmented package [Muggeo, 2003, 2008]). Before the breakpoint, the model identified an increase in SRP loss with 

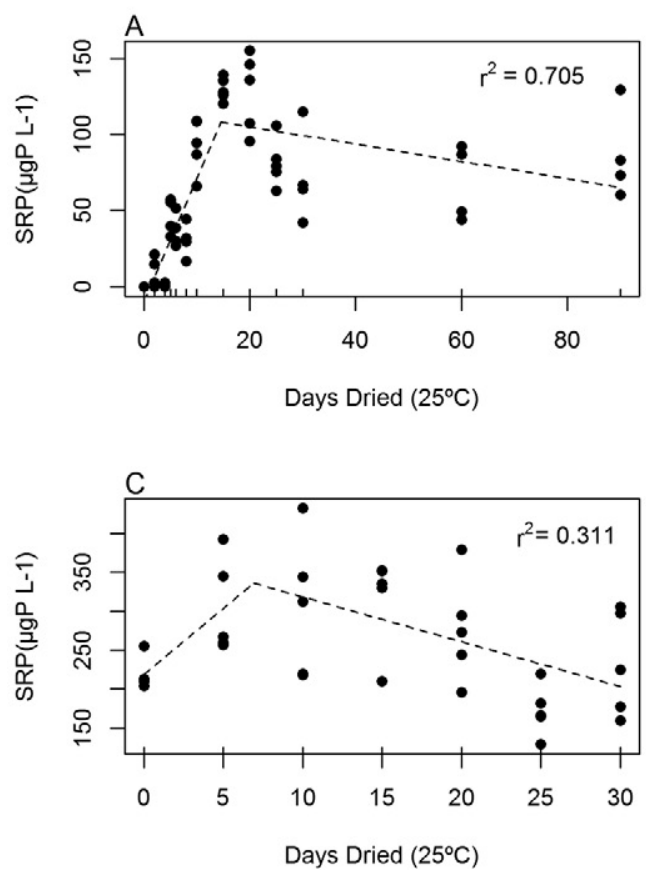
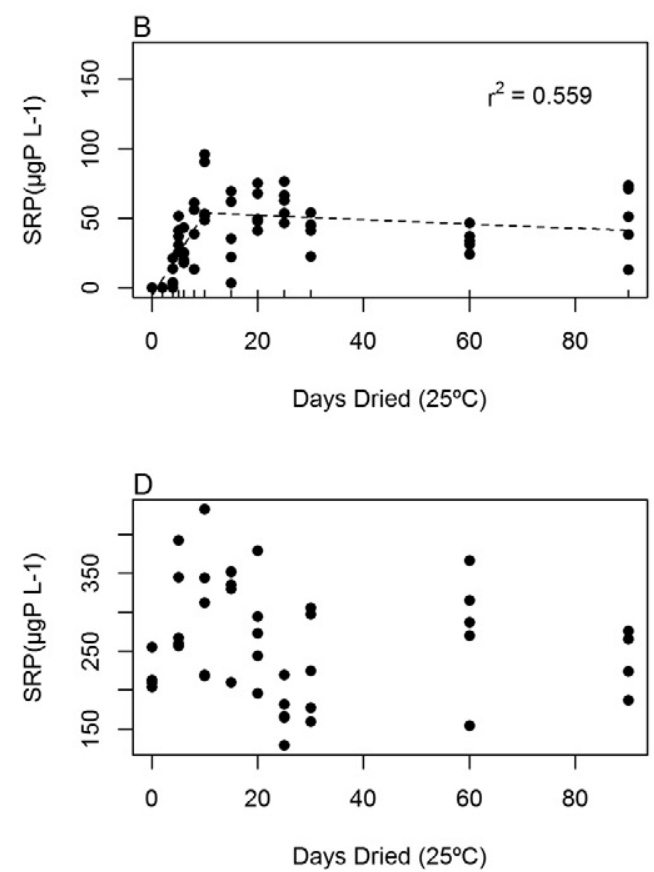

Fig. 1. Soluble reactive phosphorus (SRP) ( $\mu \mathrm{g} \mathrm{PL}^{-1}$ ) plotted against the duration of time dried $\left(a t 25^{\circ} \mathrm{C}\right.$ ) in days for the (A) Newby, (B) Pow, and (C) Blackwater (0-30 d data), and (D) complete dataset. The segmented model prediction (dashed line) suggests that the significant breakpoint in the data is at $14.5\left(r^{2}=0.705\right)$ for Newby, $10.0\left(r^{2}=0.559\right)$ for Pow, and $6.9\left(r^{2}=0.311\right)$ d for Blackwater, where the relationship between the duration of time (d) dried and SRP solubilization changes. the number of dry days, but after this point, the amount of SRP solubilized was reduced or stayed fairly constant. The Newby soil identifies well with the model $\left(r^{2}=0.705\right)$, yet contrastingly, the Blackwater soil does not $\left(r^{2}=0.311\right)$. Greater percentage C does not yield greater concentrations of SRP in leachate, but it may account for the more pronounced breakpoint response from the Newby and Pow soils (Nguyen and Marschner, 2005). There was not, however, a clear decrease of mean average SRP concentration in leachate between each drying increment subsequent to the breakpoint (Supplemental Table S4). At these breakpoints, nonetheless, up to $28 \%$ more SRP in leachate was yielded (solubilized) than in lesser and longer drying periods.

Matric potential in all soils rapidly increased (values more negative) between 0 and $5 \mathrm{~d}$ of drying time (Supplemental Table S4). Breakpoints were identified for all soils at $5.3 \pm 0.2 \mathrm{~d}\left(r^{2}\right.$ $=0.943$ ) (mean average reported). After this breakpoint, matric potential did not change significantly, meaning that the ability of water to move through the soils remained similar. Soil preparation (sieving to $2 \mathrm{~mm}$ ), along with the experimental conditions under which the soils were dried (temperature controlled room at $25^{\circ} \mathrm{C}$ ), could have significantly exacerbated the drying process, resulting in the shorter matric potential breakpoint compared with the SRP breakpoint. As the breakpoint drying times have been identified in a laboratory environment, they are likely to differ in the field, where it would take longer to attain the same degree of dryness (matric potential). However, the frequency of longer drying events increases under climate change, so the effect may still be true in the field and, indeed, be more pronounced as drying will predominantly occur at the surface (where $\mathrm{P}$ is more concentrated), gradually spreading down the soil profile to, for example, the depth sampled here. Soil preparation likely removed some of the natural drying features that would occur to soil in the field on drying, as sieving can remove preferential flow characteristics (Koestel et al., 2012) that can enhance P loss to waterbodies (Sharpley et al., 2013) and root removal can modify soil structure and affect water retention (Daly et al., 2015). Nonetheless, some artificial pathways would have been created as the dry soil was repacked, in addition to the microcracks potentially formed on rewetting (Grant and Dexter, 1989), affecting the rate of water flow with differing kinetic energies (Blackwell et al., 2009) and possibly contributing to the variation between repetitions of SRP concentration in leachate. Increased cracking and preferential pathways, together with increased hydrophobicity of the soil, may be responsible for the diminished SRP concentration after the breakpoint; further investigation is warranted as to whether this process was the cause for the observed breakpoint. With this dataset, however, no relationship could be found between matric potential and SRP concentration in leachate.

Increased frequency of dry periods between 6 and $55 \mathrm{~d}$ under climate change could yield a total change in mobilized

Table 1. Results of segmented linear regression for Newby Beck, Pow Beck, and Blackwater soils (standard error) for matric potential and soluble reactive phosphorus (SRP), and the increased frequency of breakpoints and potentially leachable SRP under UKCP09 medium emissions climate change.

\begin{tabular}{|c|c|c|c|c|c|c|c|}
\hline Soil & $\begin{array}{l}\text { Breakpoint (d) } \\
\text { SRP }\end{array}$ & $\begin{array}{l}\text { Segmented } \\
\text { regression } R^{2} \\
\text { SRP }\end{array}$ & $\begin{array}{c}\text { Potentially } \\
\text { leachable SRP } \\
\text { at breakpoint } \\
\text { (segmented model) }\end{array}$ & $\begin{array}{c}\text { Potentially } \\
\text { leachable SRP } \\
\text { at breakpoint } \\
\text { (collected data) }\end{array}$ & $\begin{array}{l}\text { Increased } \\
\text { frequency of } \\
\text { breakpoint } \\
\text { occurring under } \\
\text { climate change }\end{array}$ & $\begin{array}{c}\text { Increased } \\
\text { potentially } \\
\text { leachable SRP } \\
\text { under climate } \\
\text { change }(6-55 \mathrm{~d})\end{array}$ & $\begin{array}{c}\text { Increased } \\
\text { frequency of 7-15 } \\
\text { dry d occurring } \\
\text { under climate } \\
\text { change }\end{array}$ \\
\hline & $d$ & & \multicolumn{2}{|c|}{$\mu \mathrm{gPL}^{-1}$} & 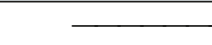 & $\%$ & 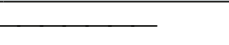 \\
\hline Newby & $14.5(1.8)$ & 0.705 & 108 & $129(8)$ & 28 & 13 & 6 \\
\hline Pow & $10.0(1.4)$ & 0.559 & 318 & $68(23)$ & 13 & 11 & 8 \\
\hline Blackwater & $6.9(2.3)$ & 0.311 & 336 & & -13 & -1 & -4 \\
\hline
\end{tabular}


SRP via solubilization of 13,11 , and $-1 \%$ for Newby, Pow, and Blackwater soils, respectively (Table 1). Increased frequency of dry periods of 11 to $55 \mathrm{~d}$ under climate change could yield a total change in SRP solubilized of 31,38 , and $21 \%$ for Newby, Pow, and Blackwater soils, respectively. Increased frequency of estimated breakpoints at 7 to $15 \mathrm{~d}$ under climate change will likely increase SRP solubilization for the Newby and Pow soils (6 and 8\% respectively) but decrease SRP solubilization in the Blackwater soil (-4\%) (Table 1). Air-drying soil changes the solubility of $\mathrm{P}$ and may not reflect true solubility in the field (Soinne et al., 2010), so translation of these laboratory results to the field scale should be treated cautiously. However, the identification of a breakpoint in SRP solubilization from soil is novel and important. The increased frequency of shorter dry days (11-15 d) may therefore be more important to consider as greater concentrations of SRP in leachate were found. Scalenghe et al. (2002) similarly found that under reducing conditions (albeit under flooding), the maximum rate of solubilization occurred within 1 to $3 \mathrm{wk}$. It would be useful, therefore, to investigate this further with a greater variety of soils.

\section{Conclusion}

Under climate change projections, the duration and frequency of dry periods will increase compared with present-day conditions in three contrasting UK catchments. For three soils, we identified critical breakpoints (6.9-14.5 d) of drying duration. Before the breakpoint, an increase in SRP loss with the number of dry days was observed; after this point, the amount of SRP lost decreased or stayed fairly constant. The frequency of these breakpoints occurring under climate change was predicted to increase and therefore yield an increase in SRP solubilization in only two of the studied soils (Table 1). It is likely that longer periods of dry days followed by rapid rewetting events will not yield more $S R P$ via solubilization than at the breakpoint. However, because the frequency of longer dry periods will increase under climate change, the solubilization of SRP from soil (-1 to 13\%) will also change. Therefore, we can accept our original hypothesis that changes in the future patterns of DRW affect the amount of SRP solubilized.

\section{Supplemental Material}

Supplemental material includes further detail of the results from the Weather Generator analysis and soil experiments and is available online.

\section{Data}

The data underlying the figures in this manuscript are openly available from Lancaster University data archive at http://dx.doi.org/10.17635/ lancaster/researchdata/170.

\section{Acknowledgments}

This work was funded by the Natural Environment Research Council (NERC) under the Changing Water Cycles Programme; projects NE/ K002392/1, NE/K002430/1, NE/K002406/1 (NUTCAT 2050) and supported by the Joint UK BEIS/Defra Met Office Hadley Centre Climate Programme (GA01101).We acknowledge the Demonstration Test Catchment (DTC) project for assistance with collection of soils. The UK Climate Projections have been made available by the Department for Environment, Food and Rural Affairs (Defra) and the Department of Energy and Climate Change (DECC) under license from the Met Office, UKCIP, British Atmospheric Data Centre, Newcastle University,
University of East Anglia, Environment Agency, Tyndall Centre, and Proudman Oceanographic Laboratory. These organizations give no warranties, express or implied, as to the accuracy of the UKCP09 and do not accept any liability for loss or damage, which may arise from reliance on the UKCP09, and any use of the UKCP09 is undertaken entirely at the user's risk.

\section{References}

Bartlett, R., and B. James. 1980. Studying dried, stored soil samplessome pitfalls. Soil Sci. Soc. Am. J. 44:721-724. doi:10.2136/ sssaj1980.03615995004400040011x

Blackwell, M.S.A., P.C. Brookes, N. de la Fuente-Martinez, P.J. Murray, K.E. Snars, J.K. Williams, et al. 2009. Effects of soil drying and rate of re-wetting on concentrations and forms of phosphorus in leachate. Biol. Fertil. Soils 45:635-643. doi:10.1007/s00374-009-0375-x

Blackwell, M.S.A., A.M. Carswell, and R. Bol. 2012. Variations in concentrations of $\mathrm{N}$ and $\mathrm{P}$ forms in leachates from dried soils rewetted at different rates. Biol. Fertil. Soils 49:79-87. doi:10.1007/s00374-012-0700-7

Bünemann, E.K., B. Keller, D. Hoop, K. Jud, P. Boivin, and E. Frossard. 2013. Increased availability of phosphorus after drying and rewetting of a grassland soil: Processes and plant use. Plant Soil. doi:10.1007/ s11104-013-1651-y

Butterly, C.R., E.K. Bünemann, A.M. McNeill, J.A. Baldock, and P. Marschner. 2009. Carbon pulses but not phosphorus pulses are related to decreases in microbial biomass during repeated drying and rewetting of soils. Soil Biol. Biochem. 41:1406-1416. doi:10.1016/j.soilbio.2009.03.018

Butterly, C.R., A.M. McNeill, J.A. Baldock, and P. Marschner. 2011a. Changes in water content of two agricultural soils does not alter labile $\mathrm{P}$ and $\mathrm{C}$ pools. Plant Soil 348:185-201. doi:10.1007/s11104-011-0931-7

Butterly, C.R., A.M. McNeill, J.A. Baldock, and P. Marschner. 2011b. Rapid changes in carbon and phosphorus after rewetting of dry soil. Biol. Fertil. Soils 47:41-50. doi:10.1007/s00374-010-0500-x

Chen, H., L. Lai, X. Zhao, G. Li, and Q. Lin. 2016. Soil microbial biomass carbon and phosphorus as affected by frequent drying-rewetting. Soil Res. 54: 321-327. doi:10.1071/SR14299

Chepkwony, C.K., R.J. Haynes, R.S. Swift, and R. Harrison. 2001. Mineralization of soil organic $\mathrm{P}$ induced by drying and rewetting as a source of plant-available $P$ in limed and unlimed samples of an acid soil. Plant Soil 234:83-90. doi:10.1023/A:1010541000437

Cranfield University. 2017. The soils guide. Cranfield University, Cranfield, UK.

Daly, K.R., S.J. Mooney, M.J. Bennett, N.M.J. Crout, T. Roose, and S.R. Tracy. 2015. Assessing the influence of the rhizosphere on soil hydraulic properties using $\mathrm{x}$-ray computed tomography and numerical modelling. J. Exp. Bot. 66:2305-2314. doi:10.1093/jxb/eru509

Dinh, M.-V., A. Guhr, M. Spohn, and E. Matzner. 2017. Release of phosphorus from soil bacterial and fungal biomass following drying/rewetting. Soil Biol. Biochem. 110:1-7. doi:10.1016/j.soilbio.2017.02.014

European Commission. 2012. Report from the commission to the European Parliament and the council on the implementation of the water framework directive $(2000 / 60 / \mathrm{ec})$ river basin management plans: UK. European Commission, Brussels, Belgium.

Fierer, N., J.P. Schimel, and P.A. Holden. 2002. Influence of drying-rewetting frequency on soil bacterial community structure. Microb. Ecol. 45:63-71. doi: $10.1007 / \mathrm{s} 00248-002-1007-2$

Grant, C.D., and A.R. Dexter. 1989. Generation of microcracks in molded soils by rapid wetting. Soil Res. 27:169-182. doi:10.1071/SR9890169

Haygarth, P.M., L.M. Condron, A.L. Heathwaite, B.L. Turner, and G.P. Harris. 2005. The phosphorus transfer continuum: Linking source to impact with an interdisciplinary and multi-scaled approach. Sci. Total Environ. 344:5-14. doi:10.1016/j.scitotenv.2005.02.001

Haynes, R.J., and R.S. Swift. 1985. Effects of air-drying on the adsorption and desorption of phosphate and levels of extractable phosphate in a group of acid soils, New Zealand. Geoderma 35:145-157. doi:10.1016/0016-7061(85)90027-8

IPCC. 2014. Climate change 2014: Synthesis report. Contribution of Working Groups I, II, and III to the Fifth Assessment Report of the Intergovernmental Panel on Climate Change. IPCC, Geneva.

IUSS Working Group WRB. 2015. World reference base for soil resources 2014, update 2015: International soil classification system for naming soils and creating legends for soil maps. World Soil Resources Rep. 106. FAO, Rome.

Jarvie, H.P., A.N. Sharpley, P.J.A. Withers, J.T. Scott, B.E. Haggard, and C. Neal. 2013. Phosphorus mitigation to control river eutrophication: Murky waters, inconvenient truths, and "postnormal" science. J. Environ. Qual. 42(2):295-304. doi: $10.2134 /$ jeq2012.0085 
Joosse, P.J., and D.B. Baker. 2011. Context for re-evaluating agricultural source phosphorus loadings to the great lakes. Can. J. Soil Sci. 91:317-327. doi: $10.4141 /$ cjss 10005

Kendon, E., N. Roberts, H. Fowler, M. Roberts, S. Chan, and C. Senior. 2014 Heavier summer downpours with climate change revealed by weather forecast resolution model. Nat. Clim. Chang. 4:570-576. doi:10.1038/ nclimate2258

Kleinman, P.J.A., A.N. Sharpley, P.J.A. Withers, L. Bergström, L.T. Johnson, and D.G. Doody. 2015. Implementing agricultural phosphorus science and management to combat eutrophication. Ambio 44:297-310. doi:10.1007/s13280-015-0631-2

Koestel, J., J. Moeys, and N. Jarvis. 2012. Meta-analysis of the effects of soil properties, site factors and experimental conditions on solute transport. Hydrol. Earth Syst. Sci. 16:1647-1665. doi:10.5194/hess-16-1647-2012

McGonigle, D.F., S.P. Burke, A.L. Collins, R. Gartner, M.R. Haft, R.C. Harris, et al. 2014. Developing demonstration test catchments as a platform for transdisciplinary land management research in England and Wales. Environ. Sci. Process. Impacts 16:1618-1628. doi:10.1039/C3EM00658A

Muggeo, V.M.R. 2003. Estimating regression models with unknown breakpoints. Stat. Med. 22:3055-3071.

Muggeo, V.M.R. 2008. segmented: An R package to fit regression models with broken-line relationships. R News 8(1):20-25. http://cran.r-project.org/ doc/Rnews/.

Murphy, J., and J.P. Riley. 1962. A modified single solution method for the determination of phosphate in natural waters. Anal. Chim. Acta 27:31-36. doi:10.1016/S0003-2670(00)88444-5

Nguyen, T.B., and P. Marschner. 2005. Effect of drying and rewetting on phosphorus transformations in red brown soils with different soil organic matter content. Soil Biol. Biochem. 37:1573-1576. doi:10.1016/j. soilbio.2005.01.015

NSRI. 2014. The soils guide. National Soil Resources Institute, Cranfield University, Cranfield, UK.

Ockenden, M., C. Deasy, C. Benskin, K. Beven, S. Burke, A.L. Collins, et al. 2016. Changing climate and nutrient transfers: Evidence from high temporal resolution concentration-flow dynamics in headwater catchments. Sci. Total Environ. 548-549:325-339. doi:10.1016/j.scitotenv.2015.12.086

Olsen, S.R., and L.E. Sommers. 1982. Determination of available phosphorus. In: A.L. Page, R.H. Miller, and D.R. Keeney, editors, Method of soil analysis. ASA, Madison, WI.

Outram, F.N., R.J. Cooper, G. Sünnenberg, K.M. Hiscock, and A.A. Lovett. 2016. Antecedent conditions, hydrological connectivity, and anthropogenic inputs: Factors affecting nitrate and phosphorus transfers to agricultural headwater streams. Sci. Total Environ. 545-546:184-199. doi:10.1016/j.scitotenv.2015.12.025

Outram, F.N., C.E.M. Lloyd, J. Jonczyk, M.C.H. Benskin, F. Grant, M.T. Perks, et al. 2014. High-frequency monitoring of nitrogen and phosphorus response in three rural catchments to the end of the 2011-2012 drought in England. Hydrol. Earth Syst. Sci. 18:3429-3448. doi:10.5194/ hess-18-3429-2014

Pailler, A., M. Vennetier, F. Torre, C. Ripert, and D. Guiral. 2014. Forest soil microbial functional patterns and response to a drought and warming event: Key role of climate-plant-soil interactions at a regional scale. Soil Biol. Biochem. 70:1-4. doi:10.1016/j.soilbio.2013.12.003
Powers, S.M., T.W. Bruulsema, T.P. Burt, N.I. Chan, J.J. Elser, P.M. Haygarth, et al. 2016. Long-term accumulation and transport of anthropogenic phosphorus in three river basins. Nat. Geosci. 9:353-356. doi:10.1038/ ngeo2693

Rowell, D.L. 1994. Soil science: Methods and applications. Prentice Hall, Pearson Education, Harlow, UK.

Rowland, A.P., and H.M. Grimshaw. 1985. A wet oxidation procedure suitable for total nitrogen and phosphorus in soil. Commun. Soil Sci. Plant Anal. 16:551-560. doi:10.1080/00103628509367628

Scalenghe, R., A.C. Edwards, F. Ajmone Marsan, and E. Barberis. 2002. The effect of reducing conditions on the solubility of phosphorus in a diverse range of European agricultural soils. Eur. J. Soil Sci. 53:439-447. doi:10.1046/j.1365-2389.2002.00462.x

Schlichting, A., and P. Leinweber. 2002. Effects of pretreatment on sequentiallyextracted phosphorus fractions from peat soils. Commun. Soil Sci. Plant Anal. 33:1617-1627. doi:10.1081/CSS-120004303

Sharpley, A., H.P. Jarvie, A. Buda, L. May, B. Spears, and P. Kleinman. 2013. Phosphorus legacy: Overcoming the effects of past management practices to mitigate future water quality impairment. J. Environ. Qual. 42:13081326. doi:10.2134/jeq2013.03.0098

Snell, M.A., P.A. Barker, B.W.J. Surridge, A.R.G. Large, J. Jonczyk, M.C.H. Benskin, et al. 2014. High frequency variability of environmental drivers determining benthic community dynamics in headwater streams. Env. Sci. Process. Impact. 16:1629-1636. doi:10.1039/c3em00680h

Soinne, H., M. Räty, and H. Hartikainen. 2010. Effect of air-drying on phosphorus fractions in clay soil. J. Plant Nutr. Soil Sci. 173:332-336. doi:10.1002/ jpln.200900225

Styles, D., and C. Coxon. 2006. Laboratory drying of organic-matter rich soils: Phosphorus solubility effects, influence of soil characteristics, and consequences for environmental interpretation. Geoderma 136:120-135. doi:10.1016/j.geoderma.2006.03.017

Styles, D., and C. Coxon. 2007. Meteorological and management influences on seasonal variation in phosphorus fractions extracted from soils in western Ireland. Geoderma 142:152-164. doi:10.1016/j.geoderma.2007.08.008

Turner, B.L., and P.M. Haygarth. 2001. Biogeochemistry: Phosphorus solubilization in rewetted soils. Nature 411. doi:10.1038/35077146

UKCP. 2009. Weather generator. http://ukclimateprojections.Metoffice.Gov. $\mathrm{Uk} / 23261$

Wade, A.J., E.J. Palmer-Felgate, S.J. Halliday, R.A. Skeffington, M. Loewenthal, H.P. Jarvie, et al. 2012. Hydrochemical processes in lowland rivers: Insights from in situ, high-resolution monitoring. Hydrol. Earth Syst. Sci. 16:4323-4342. doi:10.5194/hess-16-4323-2012

Wang, Y., Y. Hao, X. Cui, H. Zhao, C. Xu, X. Zhou, et al. 2013. Responses of soil respiration and its components to drought stress. J. Soils Sediments 14:99-109. doi:10.1007/s11368-013-0799-7

Xu, G., J.N. Sun, R.F. Xu, Y.C. Lv, K. Yan, L.H. Zhang, et al. 2011. Effects of airdrying and freezing on phosphorus fractions in soils with different organic matter contents. Plant Soil Environ. 57:228-234. 